\title{
IMPLEMENTASI PROGRAM JAMINAN KESEHATAN (JKN) DALAM PRESFEKTIF PELAYANAN PUBLIK DI RSUD Dr DORIS SYLVANUS PALANGKA RAYA
}

\author{
Program Assurance Service Of Health (JKN) Presfective In Public \\ In Rsud Dr. Doris Sylvanus Palangka Raya
}

\section{Milka*}

Universitas Muhammadiyah Palangkaraya, Palangka Raya, Central Kalimantan, Indonesia

email: milkaniez22@gmail.com

\section{Kata Kunci:}

Implementasi

Program JKN

Pelayanan Publik

Keywords:

Implementation

JKN Program

Public services

\section{Accepted}

June 2018

\section{Published}

October 2018

\begin{abstract}
Abstrak
Kajian ini bertujuan untuk Mengetahui dan Menganalisis Pelaksanaan Program Jaminan Kesehatan (JKN) Dalam Prespektif Pelayanan Publik di Rumah Sakit Umum Daerah dr. Doris Sylvanus Palangka Raya. Metode yang digunakan dalam penelitian ini adalah Kualitatif dengan jenis deskritif kualitatif. Tehnik pengumpulan data observasi, wawancara dan dokumentasi, Uji observasi menggunakan Standar Operasional Prosedur Program Jaminan Kesehatan Nasional (JKN) dan menggunakan Prinsip dan Asas Pelayanan Publik
\end{abstract}

Hasilnya menunjukan bahwa I). Perlu adanya perbaikan pelayanan baik dari segi pelayanana administrasi, Pelayanana Kesehatan secara langsung, dan perlu penambahan sumber daya manusia, disertai sarana dan prasarana. 2). Perlu menjalin komunikasi yang intensif antara Badan Penyelenggaraan Jaminan Sosial Kesehatan, dan Rumah Sakit Umum Daerah dr. Doris Sylvanus Palangka Raya, terkait dengan penyelenggaraan pelayanan, pemberian pelayanan dan alur pelayanan kesehatan. Serta Informasi terkait pelaksanaan progam JKN di Rumah Sakit Umum Daerah dr. Doris Sylvanus Palangka Raya

Rekomendasi I. Perlu adanya perbaikan pelayanan baik dari segi pelayanana administrasi, Pelayanana Kesehatan secara langsung, dan penambahan sumber daya manusia, disertai sarana dan prasarana. 2. Perlu menjalin komunikasi yang intensif antara Badan Penyelenggaraan Jaminan Sosial Kesehatan, dan Rumah Sakit Umum Daerah dr. Doris Sylvanus Palangka Raya, terkait dengan penyelenggaraan pelayanan, pemberian pelayanan dan alur pelayanan kesehatan. 3. Perlu adanya dukungan dari pemerintah pusat dan daerah baik legislatif maupun eksekutif dalam mengalokasikan anggaran dalam peningkatan sarana dan pasarana.

\begin{abstract}
This study aims to: find out and analyze the implementation of the Health Insurance Program (JKN) in the perspective of public services at the Regional General Hospital, dr. Doris Sylvanus Palangka Raya. The method used in this research is qualitative with qualitative descriptive type. Observation data collection techniques, interviews and documentation, Observation test uses the Standard Operating Procedure of the National Health Insurance Program (JKN) and uses the Principles and Principles of Public Service.

The results show that I). There needs to be improved services both in terms of administrative services, direct health services, and the need for additional human resources, accompanied by facilities and infrastructure. 2). Need to establish intensive communication between the Health Social Security Administration Agency, and the Regional General Hospital dr. Doris Sylvanus Palangka Raya, related to service delivery, service delivery and health service flow. As well as information related to the implementation of the JKN program at the Regional General Hospital, dr. Doris Sylvanus Palangka Raya.
\end{abstract}

Recommendations $I$. There is a need to improve services both in terms of administrative services, health services directly, and the addition of human resources, accompanied by facilities and infrastructure. 2. It is necessary to establish intensive communication between the Health Social Security Administration Agency, and the Regional General Hospital, dr. Doris Sylvanus Palangka Raya, related to service delivery, service delivery and health service flow. 3. There needs to be support from the central and regional governments both legislative and executive in allocating budgets in improving facilities and markets. 


\section{PENDAHULUAN}

Kesehatan merupakan salah satu kebutuhan dasar masyarakat, maka kesehatan adalah hak bagi setiap warga masyarakat yang dilindungi oleh Negara, Oleh karena itu perbaikan pelayanan kesehatan pada dasarnya merupakan suatu investasi sumber daya manusia untuk mencapai masyarakat yang sejahtra (walfare society). Demi meningkatkan kesehatan masyarakat, maka pemerintah membuat program kesehatan demi membantu meringankan biaya berobat kepada seluruh masyarakat.

Berdasarkan standar pelayanan program BPJS Kesehatan maka peserta BPJS Kesehatan wajib menerima pelayanan sebagaimana yang telah diatur dalam undang-undang No. II tahun 20II. Bentuk program jaminan kesehatan yang sering digunakan oleh masyarakat adalah Jaminan Kesehatan Nasional (JKN) merupakan salah satu program yang termasuk didalam Badan Penyelenggaraan Jaminan Sosial (BPJS) yang berfungsi untuk digunakan masyarakat untuk meringankan biaya berobat. Pasien Jaminan Kesehatan Nasional (JKN) dapat digunakan di Puskesmas maupun di Rumah Sakit. Namun seperti kita ketahui program yang dibuat oleh pemerintah tidak selamanya dapat berjalan sesuai dengan keinginan pemerintah.

Meskipun biaya kesehatan relative murah bukan berati bahwa pelayanan yang diberikan rendah dan tidak berkualitas. Murahnya biaya pelayanan kesehatan itu adalah karena adanya subsidi yang besar dan adanya kontribusi masyarakat dan dunia bisnis dalam bentuk donasi. Sering kali adanya berbedaan penanganan yang diterima di rumah sakit antara pasien BPJS dan pasien umum serta pasien BPJS Kesehatan terkesan lamban ditangani.

Berdasarkan observasi yang dilakukan, terdapat penomena yang terjadi di Rumah Sakit Umum Daerah dr. Doris Sylvanus Palangka Raya terkait pemberian pelayanan kesehatan bagi peserta Jaminan Kesehatan Nasional (JKN) mengeluh tentang pelayanan yang diberikan kepada mereka. Seperti Misalnya Para Pasien BPJS Kesehatan yang sudah mengantri panjang dan lama untuk mendapatkan pengobatan dan ruangan rawat inap namun mereka tidak mendapatkan ruangan rawat inap, bahkan ada pasien yang menunggu berharihari di ruangan Intalasi Gawat Darurat untuk mendapatkan ruang perawatan. Para pasien Jaminan Kesehatan Nasional juga mengeluhkan pelayanan yang diberikan oleh petugas medis lambatnya penanganan terhadap pasien Badan Penyelenggaraan Jaminan Sosial (BPJS.

Kesehatan serta kuranya perhatian, sikap, para petugas dalam menangani keluhan pasien, disertai dengan perbedaan perlakuan yang diterima pasien umum dan pasien BPJS Kesehatan, Sedangka hakikat dasar dari rumah sakit adalah pemenuhan kebutuhan dan tuntutan pasien yang mengharapkan penyelesaian masalah kesehatannya pada rumah sakit karena dianggap rumah sakit mampu memberikan pelayanan medis sebagai upaya penyembuhan dan pemulihan penyakitnya dan pasien mengharapkan pelayanan yang cepat, tepat, dan nyaman.

Pelayanan yang cepat, tepat dan nyaman sangat ditentukan oleh sumber daya manusia, fasilitas, saranan dan prasarana pelayanan. Dalam hal pelayanan pasien yang berobat (sakit) menginginkan pelayanan yang cepat tidak menunggu terlalu lama, pemberian pengobatan sesuai dengan keluhan pasien dan selama dilayani pasien merasa nyaman.

Menurut Moenir (2015 : 192) bahwa pelayanan publik adalah kegiatan yang dilakukan oleh seseorang atau sekelompok orang dengan landasan faktor material melalui sistem, prosedur, dan metode tertentu dalam usaha memenuhi kepentingan orang lain sesuai dengan haknya. Kegiatan pelayanan publik yang diselenggarakan oleh pemerintah kepeda masyarakat meliputi banyak hal yang menyangkut semua kebutuhan masyarakat.

Pada prinsipnya pelayanan publik senantiasa selalu ditingkatkan kinerjanya sesuai dengan keinginan 
masyarakat pengguna jasa. Standar Pelayanan Publik menurut Keputusan Menteri Pemberdaya Aparatur Negara nomor 63/KEP/M.PAN/7/20I3, sekurangkurangnya meliputi :

I). Prosedur Pelayanan

2). Waktu Pelayanan

3). Biaya Pelayanan

4). Produk Pelayana

5). Sarana dan Prasarana

6). Komponen Petugas Pelayanan

Pelayanan kesehatan tingkat pertama, yakni pelayanan kesehatan non spesialistik mencakup :

a. Administrasi Pelayanan

b. Pelayanan Promoti dan preventif

c. Pemeriksaan, pengobatan dan konsultasi medis

d. Tindakan medis non spesialistik, baik operatif maupun non operatif

e. Pelayanan obat dan bahan medis habis pakai

f. Transfusi darah sesuai dengan kebutuhan medis

g. Pemeriksaan penunjang diagnostik laboratorium tingkat pertama dan

h. Rawat inap tingkat pertama sesuai dengan indikasi

\section{METODOLOGI}

Pendekatan yang digunakan dalam penelitian ini adalah kualitatif digunakan untuk mengetahui serta melukiskan keadaan yang sebenarnya secara rinci dan aktual dengan melihat masalah dan tujuan peneliti. Moleong (Herdiansyah, 2009:9) penelitian kualitatif adalah penelitian yang bermaksud untuk memahami fenomena tentang apa yang dipahami oleh subjek penelitian, misalnya perilaku, persepsi, motivasi, tindakan, dan lain sebagainya. Dengan Hasil Observasi, wawancara, dokumentasi.

\section{HASIL DAN PEMBAHASAN}

Daya Dukung Program JKN melalui BPJS Kesehatan menggunakan beberapa media dalam proses sosialisasinya. Media komunikasi yang digunakan BPJS Kesehatan Kota Palangka Raya dalam mensosialisasikan BPJS Kesehatan kepada masyarakat Kota Palangka Raya antara lain yaitu media cetak yang berupa koran, brosur, media televisi, radio, baliho dan spanduk, serta sosialisai secara langsung di car free daybundaran besar pada hari minggu.

Hambatan yang dirasakan dalam memberikan pelayanan promosi melalui media cetak yaitu kurangnya tingkat kesadaran masyarakat untuk mengetahui informasi yang disediakan oleh media cetak tersebut, hal ini terlihat dari masih banyaknya jumlah brosur yang tersedia di rak brosur, sedangkan brosur yang disediakan bersifat gratis. $\mathrm{Hal}$ ini dibenarkan oleh salah satu petugas fasilitas pelayanan tingkat pertama.

\section{Tantangan Pelayanan Bagi Peserta JKN di RSUD dr. Doris Sylvanus Palangka Raya}

Dari hasil penelitian dilapangan yang menjadi tantangan pelayanan bagi peserta BPJS Kesehatan di RSUD dr. Doris Sylvanus Palangka Raya yaitu, kurangnya sumber daya manusia dari segi perawat yang bertugas diruangan rawat inap, bidan yang bertugas diruangan persalinan, dan dokter spesialis yang dimiliki RSUD dr. Doris Sylvanus Palangka Raya, serta sarana dan prasarana penunjang pelayanan medis yang meliputi, kurangnya persediaan ruangan rawat inap, ruang tunggu pelayanan rawat inap, ruang tunggu obat dan sarana seperti kursi tunggu antrian pengambilan obat dan antrian loket pelayanan administrasi loket BPJS Kesehatan sehingga masih ada peserta BPJS Kesehatan yang berdiri menunggu antrian, tidak efektifnya penggunaan alat pendingin udara seperti kipas angin yang tidak tersedia di ruang tunggu, bahkan pendingin ruangan yang tidak berfungsi diruangan rawat inap kelas III, serta kurangnya alat medis seperti selang infus yang tersedia diruangan rawat inap yang memadai bagi 
peserta BPJS Kesehatan di RSUD dr. Doris Sylvanus Palangka Raya.

I. Kurangnya Sumber Daya Manusia yang Ada Sesuai dengan Standar Operasional yang Dimiliki Setiap Rumah Sakit.

Peranan sumber daya bagi Pelaksanaan Program sebuah kebijakan memiliki peranan yang sangat penting terutama sumber daya manusia, dari segi keterampilan staf administrasi, perawat, dokter, dan tenaga medis yang bertugas yang didukung dengan sumber daya anggaran, sebuah kebijakan akan berjalan dengan maksimal apabila sumber daya manusia dan sumber daya finansial tercukupi. Kebijakan pastilah memerlukan sumber daya untuk menjamin keberlangsungan kebijakan tersebut baik itu sumber daya manusia maupun sumber daya anggaran. Sumber daya manusia sebagai implementasi suatu kebijakan, sehingga dapat berjalan secara efisisien apabila sumber dayanya mencukupi dan dapat bekerja secara profesional dan efektif didalam menjalankan sebuah program sesuai dengan rumusan kebijakan yang telah ditentukan. Adapun sumber daya finansial juga memiliki kedudukan yang sangat penting karena implementasi kebijakan tidak akan berjalan apabila secara finansial tidak mencukupi. Akibat dari kurangnya sumber daya yang dimiliki implementasi kebijakan akan berjalan lamban.

Dari sumber daya yang dimiliki Rumah Sakit Umum Daerah dr. Doris Sylvanus Palangka Raya, kurangnyadokterspesialis, bidan, dan perawat, dokter dengan jumlah tenaga medis yang tersedia di Rumah Sakit Umum Daerah dr. Doris Sylvanus Palangka Raya tidak sebanding dengan jumlah pasien yaitu 8:I di ruangan. Dari hasil penelitian ditemukan bahwa tenaga medis yang bertugas di RSUD dr. Doris Sylvanus Palangka Raya khususnya pada pelayanan menyebabkan lambat dan panjang waktu penyelesaian pelayanan.
2. Kurangnya Sarana dan prasarana yang ada sesuai dengan stadar pelayanan Rumah Sakit dR. Doris Sylvanus Palangka Raya.

Sarana dan Prasarana merupakan hal yang sangat penting sebagai alat penunjang keberhasilan suatu proses yang dilakukan. Dengan demikian, suatu proses kegiatan yang akan dilakukan tidak akan dapat mencapai hasil yang diharapkan sesuai dengan rencana, Sarana pelayanan yang dimaksud ialah segala peralatan, perlengkapan kerja dan fasilitas lain yang berfungsi sebagai alat atau pembantu dalam pelaksanaan pekerjaan, sarana dan prasaranayang dimaksud adalah ketersedian ruangan rawat inap, ruang tunggu rawat inap dan rawat jalan, kemudahan untuk mendapatkan fasilitas pelayanan, ketersediaan alat medis, peralatan kerja, perlengkapan kerja yang tersedia di Rumah Sakit Umum Daerah dr. Doris Sylvanus Palangka Raya.

Berdasarkan hasil wawancara dan observasi yang dilakukan peneliti mengenai sarana dan prasarana yang cukup memadai dalam menunjang pelayanan kesehatan bagi peserta BPJS Kesehatan di RSUD dr. Doris Sylvanus Palangka Raya dalam memberikan pelayanan kepada pasien sejauh ini kurang baik. Dapat dilihat dari sarana dan prasarana pelayanan seperti kondisi bangunan yang cukup usang, masih ada beberapa fasilitas yang masih kurang memadai, seperti ruang tunggu bagi pasien rawat inap kelas III yang tidak tersedia, kursi pengunjung atau tidak tersedianya ruang tunggu bagi keluarga pasien, sehingga keluarga pasien yang menunggu di teras ruangan rawat inap kelas III,bahkah masih ada peserta Jaminan Kesehatan Nasional yang menggunakan selang infus yang sudah bocor, dan tidak berfungsinya pendingin udara di ruangan rawat inap, sehingga belum sepenuhnya memenuhi keinginan pasien. Hal tersebut perlu ditingkatkan lagi oleh pihak 
RSUD untuk kepuasan pasien dan kualitas pelayanan yang lebih baik.

Sarana dan prasarana penunjang pelayanan yang dimiliki Rumah Sakit Umum Daerah dr. Doris Sylvanus Palangka Raya dirasakan masih kurang memadai dan masih banyak yang perlu ditambah dari segi ketersediaan ruangan pelayanan rawat inap yang masih kurang untuk menampung pasien rawat inap, dan tidak berfungsinya ruangan bedah karena peralatan bedah yang kurang seperti, ranjang operasi, lampu operasi dan alat medis operasi lainnya, kurangnya tempat duduk yang disediakan di ruang tunggu sehingga masih banyaknya masyarakat yang menunggu pasien di teras, dan tidak berfungsinya pendingin ruangan yang tersedia diruangan rawat inap kelas III bagi Peserta BPJS Kesehatan yang disediakan RSUD dr. Doris Sylvanus Palangka Raya.Hal inilah yang menyebabkan lambatnya waktu penyelesaian pelayanankepada peserta BPJS Kesehatan.

Dari hasil penelitian juga di dapat bahwa faktor penghambat dalam memberikan pelayanan yang berkualitas yaitu faktor sarana dan prasarana yaitu segala macam jenis peralatan, perlengkapan kerja dan fasilitas yang berfungsi sebagai alat pendukung utama dalam mempercepat pelaksanaan penyelesaiaan pekerjaan. Sarana dan prasarana yang ada pada RSUD dr. Doris Sylvanus Palangka Raya masih belum memadai, terlihat dari ketersediaan ruangan rawat inap, dan fasilitas pendukung pelayanan dan alat medis dalam pemberian pelayanan sehingga proses pelaksanaan penyelesaian pekerjaan menjadi terhambat. Dari hasil penelitian diatas dapat disimpulkan bahwa kurangnya sarana dan prasarana mengakibatkan terlambatnya waktu pelayanan kepada peserta BPJS Kesehatan.

Sehingga hasil penelitian tersebut menguraikan beberapa permsalahan, seperti :
I. Masih ditemukan adanya peserta Jaminan Kesehatan Nasional yang tidak mengetahui atau memahami alur proses registrasi pelayanan administrasi secara berjenjang khususnya bagi peserta BPJS Kesehatan yang dirujuk ke RSUD dr. Doris Sylvanus Palangka Raya

2. Masih adanya pasien yang melakukan pengobatan di Intalasi Gawat Darurat yang tidak memiliki asuransi kesehatan dengan alasan rumitnya alur pelayanan bagi peserta BPJS Kesehatan

3. Kurang tersedian sarana dan perasaranan, dari segi ruangan rawat inap, alat medis lainnya, seperti pendingin udara, kursi tunggu, dan ruang tunggu pasien rawat inap.

4. Kosongnya persedian obat, dan masih ada jenis obat yang ditebus oleh peserta BPJS Kesehatan secara pribadi

5. Tidak adanya petugas informasi khusus bagi peserta BPJS Kesehatan, dan tidak adanya petugas BPJS Kesehatan yang bertugas di RSUD

\section{KESIMPULAN}

Dari hasil penelitian dan pembahasan yang diuraikan dalam penelitian ini, maka dapat diambil beberapa kesimpulan :

I. Pelayanan kesehatan bagi peserta Jaminan Kesehatan Nasional (JKN) di Rumah Sakit Umum Daerah dr. Doris Sylvanus Palangka Raya tergolong rendah. Karena masih adanya peserta Jaminan Kesehatan Nasional yang tidak memahami alur pelayanan administrasi berjenjang di RSUD, Antrian loket registasi administrasi yang cukup panjang; diskriminasi pemberian pelayanan; tidak adanya petugas informasi yang bertugas di RSUD, faktor sumber daya manusia maupun faktor sarana dan prasarana yang dimiliki Rumah Sakit Umum Daerah dr. Doris Sylvanus Palangka Raya yang tidak diikuti dengan jumlah tenaga medis, sarana 
dan prasarana yang belum lengkap sehingga pemberian pelayanan tidak optimal.

2. Komunikasi, Sosialisai, yang kurang terjalin antara BPJS Kesehatan dengan peserta Jaminan Kesehatan Nasional (JKN) dan Rumah Sakit Umum Daerah dr. Doris Sylvanus Palangka Raya selaku penyelenggara pelayanan kesehatan, masih kurang baik mengakibatkan peserta Jaminan Kesehatan Nasional (JKN) tidak memahami prosedur administrasi dan pelayanan kesehatan.

\section{REFERENSI}

Dwiyanto, Agus, dkk. 2006 Reformasi Birokrasi Publik di Indonesia. Yogyakarya. Gadjah Mada Universitry Press

Hardiansyah. 20I4. Kualitas Pelayanan Publik Kondep, Dimensi, Indikatordan Implementasinya. Jakarta

Herabudin. 20I4. Studi Kebijak Pemerintah dari Filosofi ke Implementasi. Bandung

Hessel Nogi S. Tangkilisan, M.Si 2005. Manajemen Publik. Gramedia Widiasana Indonesia

Kementerian Kesehatan Republik Indonesia 2013. Buku Saku FAQ (Frequently Asked Questions) BPJS Kesehatan . Jakarta : Kementerian Kesehatan RI Lestari, Dwi Sri. 2015. Studi Implementasi Program Jaminan Kesehatan Masyarakat Miskin Atau Akseskin Ditinjau Dari Aspek Kepesertaan (Studi Kasus Desa Condoriya Kecamatan Gergas Kabupaten Semarang)

Marisah. 2016. Implementasi Kebijakan Peraturan Badan Penyelenggaraan Jaminan Sosial Kesehatan No. I Tahun 20/4 Tentang Penyelenggaraan Jaminan Kesehatan di Kota Samarinda

Moleong, Lexy,j. 2009. Metodelogi Penelitian Kualitatif, Edisi Revisi. PT. Remaja Rosada Karya. Bandung Mulyadi, Deddy. 2015. Studi Kebijakan Publik dan Pelayanan Publik, Konsep dan Aplikasi, Proses Kebijakan Publik dan Pelayanan Publik. Bandung
Niah, Najah Soraya. 2016. Pelaksanaaan Kebijakan Bada Penyelenggaraan Jaminan Kesehatan Sosial di Kabupaten Jombang

Ratminto dan Atik septi winarsih. 2008. Manajemen Pelayanan. Universitas gajah mada Yogyakarta. Pustaka Belajar.

Wahab, Solichin Abdul. 2000. Analisis kebijaksanaan dari formulasi ke implementasi kebijaksanaan Negara. Jakarta : Bumi Aksara

Winarno, Budi. 2007. Kebijakan Publik Teori dan Proses. Yogyakarta Median Pressindo

\section{Perundang-Undangan}

Undang-undang Republik Indonesia Nomor 24 Tahun 201 I Tentanga Badan Penyelenggaraan Jaminan Sosial

Undang-Undang Republik Indonesia Nomor 40 Tahun 2004 Tentang Sistem Jaminan Kesehatan Nasional 